\title{
WHICH SYRUP FLAVOR PEDIATRIC POPULATION PREFERS THE MOST?
}

\section{GEORGE MATHEW PANACHIYIL, TIRIN BABU}

Department of Pharmacy Practice, JSS College of Pharmacy, JSS Academy of Higher Education and Research, Mysuru, Karnataka, India. Email: tirin.babu1993@gmail.com

Received: 22 December 2020, Revised and Accepted: 30 January 2020

ABSTRACT

Objectives: To find out syrup flavor preferences among pediatric patients.

Methods: This prospective survey included 350 pediatric patients in a multispecialty hospital and was conducted for over four months. The patients filled a pro forma with a questionnaire regarding the syrup flavor preferences details among four drug categories. If the patients were unable to fill the questionnaire, the parents were asked to fill the same.

Results: In our survey, the first preference of the syrup flavors by male gender from all four drug categories were banana-vanilla, orange, lime, and orange-lemon flavors. Whereas, the same in the female gender were the following: Strawberry, grape, banana-pineapple, and strawberry-lemon flavors.

Conclusion: The creation of an acceptable syrup taste using flavors should be taken into account by the healthcare professionals before prescribing it to the children.

Keywords: Syrup, Flavors, Drugs, Pediatric patients, Medication adherence.

(C) 2021 The Authors. Published by Innovare Academic Sciences Pvt Ltd. This is an open access article under the CC BY license (http://creativecommons.org/ licenses/by/4.0/) DOI: http://dx.doi.org/10.22159/ajpcr.2021v14i4.40599. Journal homepage: https://innovareacademics.in/journals/index.php/ajpcr

\section{INTRODUCTION}

Pediatric patients often do not take drugs prescribed, which directly affects patient therapeutic outcomes [1]. Taste is an essential factor in medication adherence, particularly in pediatric patients [2]. Thus, pediatric suspensions' development and marketing must target not only efficiency but also palatability [3]. The unpleasant taste of medication is a crucial barrier to compliance for most pediatric patients with acute or chronic illness [4]. Many parents are familiar with the difficulties of convincing children to take bitter, unfamiliar medicine. Hence, palatability is an important factor influencing medication adherence and acceptability in pediatric population [5].

\section{METHODS}

This prospective survey was conducted in the inpatient pediatric department of a tertiary care hospital from February 2019 to May 2019 to determine syrup's flavor preferences among pediatric populations. A questionnaire containing different drug classes and the preferred flavors used for their formulation for masking the bitter taste of drug was prepared. A total of four drug classes were included in the questionnaire: Antibiotics, antihistamines, barbiturates, decongestants, and expectorants. Each category contains three questions:

1. Which flavor you prefer the most?

2. Which flavor is your second preference?

3. Which flavor you like the least?

Patients admitted to the pediatric ward during the study period were identified daily using the wards census registers. The survey questionnaire was given to the patients aged up to 18 years. If the patients were unable to fill the questionnaire, the parents were asked to fill the same. There were a total of 350 patients included in this survey. There was male preponderance among the enrolled patients, with being 190 (54\%) male and 160 (46\%) patients being female. The drug classes and preferred flavors during their formulations were categorized based on Sharma et al. study. The selected flavors during formulations for category A drugs (Antibiotics) are Cherry, maple, pineapple, orange, raspberry, banana-vanilla, butterscotch, coconut-custard, fruit-cinnamon, strawberry, and vanilla. For category B drugs (Antihistamines), the following are the preferred flavors: Apricot, cherry, cinnamon, grape, honey, lime, peach-orange, peachrum, raspberry, and wild cherry. Category C (Barbiturates) drugs, banana-pineapple, banana-vanilla, cinnamon-peppermint, orange, peach-orange, and grenadine-strawberry are the preferred flavors. Anise, apricot, butterscotch, cherry, coconut-custard, custard-mintstrawberry, grenadine-peach, strawberry-lemon, gooseberry, orangelemon, coriander, pineapple, and raspberry are the chosen flavors in category D (Decongestants and Expectorants) drugs [6-8].

\section{RESULTS}

In our survey, the first and second preference of the syrup flavours by male gender from all four drug categories were banana-vanilla, orange, lime, honey, cinnamon-peppermint, orange-lemon, and custard-mint-strawberry flavors. The least syrup flavour by male gender from all four types was coconut-mustard, apricot, grenadinestrawberry and anise flavors. Whereas in the female gender, the first and second preference of syrup flavors from all drug four categories were strawberry, vanilla, grape, lime, banana-pineapple, grenadinestrawberry, strawberry-lemon and butterscotch flavors. The least choice of syrup flavor by female gender from all drug four categories were Maple, peach-rum, cinnamon-peppermint and custard-mintstrawberry flavors (Table 1 ).

\section{DISCUSSION}

Children's sensory system is well-developed to detect tastes, smells, and chemical irritants and recognize sweetness and saltiness from an early stage. Furthermore, children can realize sweet taste in oral liquids and the degree of sweetness. Children have a low tolerance for disagreeable taste; hence the pediatric formulations are available in various flavors that successfully mask unpleasant tastes without affecting physical and chemical stability [9]. The formulators have found that an unpleasant taste-masking problem can best be resolved using blends of distinctive 
Table 1: Syrup flavor preferences among the pediatric population

\begin{tabular}{|c|c|c|}
\hline & Female & Male \\
\hline \multicolumn{3}{|l|}{ Category - A } \\
\hline $\begin{array}{l}\text { First } \\
\text { preference } \\
\text { flavor }\end{array}$ & Strawberry & Banana-Vanilla \\
\hline $\begin{array}{l}\text { Second } \\
\text { preference } \\
\text { flavor }\end{array}$ & Vanilla & Orange \\
\hline $\begin{array}{l}\text { Least } \\
\text { preference } \\
\text { Flavor }\end{array}$ & Maple & Coconut-Mustard \\
\hline \multicolumn{3}{|l|}{ Category - B } \\
\hline $\begin{array}{l}\text { First } \\
\text { preference } \\
\text { flavour }\end{array}$ & Grape & Lime \\
\hline $\begin{array}{l}\text { Second } \\
\text { preference } \\
\text { flavor }\end{array}$ & Lime & Honey \\
\hline $\begin{array}{l}\text { Least } \\
\text { preference } \\
\text { Flavor }\end{array}$ & Peach-Rum & Apricot \\
\hline \multicolumn{3}{|l|}{ Category - C } \\
\hline $\begin{array}{l}\text { First } \\
\text { preference } \\
\text { flavor }\end{array}$ & Banana-Pineapple & Orange \\
\hline $\begin{array}{l}\text { Second } \\
\text { preference } \\
\text { flavor }\end{array}$ & Grenadine-Strawberry & Cinnamon-Peppermint \\
\hline $\begin{array}{l}\text { Least } \\
\text { preference } \\
\text { flavor }\end{array}$ & Cinnamon-Peppermint & Grenadine-Strawberry \\
\hline \multicolumn{3}{|l|}{ Category - D } \\
\hline $\begin{array}{l}\text { First } \\
\text { preference } \\
\text { flavor }\end{array}$ & Strawberry-lemon & Orange-Lemon \\
\hline $\begin{array}{l}\text { Second } \\
\text { preference } \\
\text { flavor }\end{array}$ & Butterscotch & Custard-Mint-Strawberry \\
\hline $\begin{array}{l}\text { Least } \\
\text { preference } \\
\text { flavor }\end{array}$ & Custard-Mint-Strawberry & Anise \\
\hline
\end{tabular}

flavors. The flavor acceptance is also affected by age. In general, children like flavored fruit syrup, adults prefer a more acid taste, while many older adults find mint or wine flavors more agreeable. Flavors are selected based on the taste of the drug to be incorporated [6].

A questionnaire-based study of 414 primary care patients $(65.9 \%$ children) in Saudi Arabia examined non-adherence to short-term antibiotic therapy. One of the reasons for non-adherence to the medication is the bitter taste of the drug [10]. Retrospective studies found that medicines with negative palatability negatively influenced medication adherence, whereas drugs with good palatability positively influenced adherence [1].

\section{CONCLUSION}

In conclusion, the taste of syrup should be taken into account by the healthcare professionals before prescribing it to the children. The creation of a good syrup taste using flavors may lead to better patient adherence to the medication.

\section{ACKNOWLEDGMENTS}

The authors would like to thank the staffs and the postgraduate students of the Department of Paediatrics and Department of Clinical Pharmacy, JSS Hospital, Mysuru for their support and encouragement.

\section{AUTHOR'S CONTRIBUTIONS}

Consider the first author and second author as first authors as both have contributed equally in this study. Dr Tirin Babu and Dr George Mathew Panachiyil were equally involved in the design of the study, literature search, data collection, manuscript preparation, reviewing, editing and drafting of the manuscript to the journal.

\section{CONFLICTING INTERESTS}

The authors declared no potential conflicts of interests concerning authorship, and publication of this article.

\section{ETHICAL APPROVAL}

Approved by the Human Ethical Committee, JSS Medical College and Hospital, Mysore, Karnataka.

\section{FUNDING}

Nil.

\section{REFERENCES}

1. El-Rachidi S, LaRochelle JM, Morgan JA. Pharmacists and pediatric medication adherence: Bridging the gap. Hosp Pharm 2017;52:124-31.

2. Bradshaw H, Mitchell MJ, Edwards CJ, Stolz U, Naser O, Peck A, et al. Medication palatability affects physician prescribing preferences for common pediatric conditions. Acad Emerg Med 2016;23:1243-7.

3. Mistry P, Batchelor H, SPaeDD-UK Project (Smart Paediatric Drug Development - UK). Evidence of acceptability of oral paediatric medicines: A review. J Pharm Pharmacol 2017;69:361-76.

4. Walsh J, Cram A, Woertz K, Breitkreutz J, Winzenburg G, Turner R, et al. Playing hide and seek with poorly tasting paediatric medicines: Do not forget the excipients. Adv Drug Deliv Rev 2014;73:14-33.

5. Baguley D, Lim E, Bevan A, Pallet A, Faust SN. Prescribing for children - taste and palatability affect adherence to antibiotics: A review. Arch Dis Child 2012;97:293-7.

6. Sharma AV, Sharma PV. Flavouring agents in pharmaceutical formulations. Anc Sci Life 1988;8:38-40.

7. Chauhan R. Taste masking: A unique approach for bitter drugs. J Stem Cell Biol Transplant 2017;1:12.

8. Sohi H, Sultana Y, Khar RK. Taste masking technologies in oral pharmaceuticals: Recent developments and approaches. Drug Dev Ind Pharm 2004;30:429-48.

9. Mennella JA, Beauchamp GK. Optimizing oral medications for children. Clin Ther 2008;30:2120-32.

10. Al-Shammari SA, Khoja T, Al-Yamani MJ. Compliance with shortterm antibiotic therapy among patients attending primary health centres in Riyadh, Saudi Arabia. J R Soc Health 1995;115:231-4 